\begin{tabular}{c} 
Volume and Issues Obtainable at Center for Sustainability Research and Consultancy \\
Journal of Business and Social Review in Emerging Economies \\
ISSN: 2519-0318 \& ISSN (E): 2518-8488 \\
Volume 7: Issue 3 September 2021 \\
CSRᄃ \\
Journal homepage: www.publishing.globalcsrc.org/jbsee \\
\hline
\end{tabular}

\title{
Employee Green Behavior as a Consequence of Green HRM Practices and Ethical Leadership: The Mediating Role of Green Self Efficacy
}

* Muhammad Adnan, National College of Business Administration and Economics (NCBA\&E) Lahore, Multan Sub-campus, Pakistan

*Corresponding author's email: dr.adnanmalik1989@gmail.com

\begin{tabular}{l}
\hline ARTICLE DETAILS \\
\hline History \\
Revised format: Aug 2021 \\
Available Online: Sep 2021 \\
\hline Keywords \\
Green Human Resource, \\
Management Practices, \\
Self-Efficacy, Ethical \\
Leadership, and Employee \\
Green Behavior.
\end{tabular}

JEL Classification

$\mathrm{MO}, \mathrm{M} 10$

\begin{abstract}
Purpose: According to latest researches, corporate people are becoming more aware of the significance of ecological issues. Since the HR department may play an essential role in being "Green", GHRM (Green Human Resource Management) has emerged as a vital business strategy for firms. Researchers in Organizational Behavior and Sustainable Development have been concentrating on the role of corporate leaders in promoting Employee Green Behavior (EGB). This study investigates the impact of Green HRM practices and Ethical Leadership on Green Behavior of employees with the mediating role of Green SelfEfficacy.
\end{abstract}

Design/Methodology/Approach: Multilevel data was collected from 250 employees, working as HR managers and Heads of different industries working in Multan and Lahore regions of Pakistan. The study is using convenient sampling technique. Smart PLS-SEM was used for data analysis.

Findings: The results shows that Green HRM practices shows positive relationship with Employee Green Behavior and Selfefficacy while Ethical Leadership shows an insignificant relationship with Employee Green Behavior. Furthermore, Selfefficacy demonstrated significant inter-dependent behvior to describe above mentioned relationship.

Implications/Originality/Value: The present study can be helpful for HR managers and policy makers to get useful insight on how GHRM can contribute to get employee green behaviors. It strengthens the efficacy of organizational green HRM systems and provides theoretical based analytics to improve GHRM research.

(C) 2021, The authors, under a Creative Commons Attribution-

Recommended citation: Adnan, M. (2021). Employee's Performance as a Consequence of Employee Green Behavior as a Consequence of Green HRM Practices and Ethical Leadership: The Mediating Role of Green Self Efficacy. Journal of Business and Social Review in Emerging Economies, 7 (3), 599-612. 


\section{Introduction}

\section{Background of the study}

Employees play a critical role in achieving organizational greening by adjusting environmental actions, which is widely recognized in today's world (Lülfs \& Hahn, 2013). Various studies have examined the prior of employee environmental attitudes, in addition to the increasing interest in learning about environmental sustainability and its possible benefits to organizations. Many sustainability policies are being implemented by industries all over the world (2013). Green is considered as the color of the nature that constitutes growth and living, symbol of hope, safety, and fertility. Green HRM refer the use of every employee's behavior to promote sustainable practices and awareness in them. It contributes the duty of applying environment-friendly human resource practices ensuring lower the costs, and better employment engagement, and retention, which supports the firms to reduce employee's carbon footprint with the help of car sharing, teleconferencing, and recycling etc. To make organization environment friendly it includes;

1) Greater efficiencies,

2) Lower costs, and employee retention within organization.

GHRM startup becomes a necessary element to increase the businesses of different types around the world. It helps the organizations to focus on various opportunities to reduce costs without losing talent etc. On the other side self-efficacy of employees also participates in improving green employee behavior within organization. Those workers who consider themselves as inefficient, having a deficit in their competence increase the feeling of inefficacy (2017). The job requirements received more attention on tasks and functions in job positions, especially workload (2017). Dumont, Shen, and Deng also addressed the role of Green HRM to enhance employee green behavior.

There is a raising demand for eco-friendly environment into human resource management and research performance. Green Human Resource Management refers to green practices that encourage the use of environmentally sustainable resources in the workplace. It would raise workplace awareness and commitment to environmental management (2018). Organizations unethical attitude became prevalent over the previous decades. Unethical practices such as misleading advertisement, extending work without pay, and receiving late salaries, these behaviors have been considered as a damage to organizational morale (2013). Because of work pressure at job employees are considered as having a syndrome named as "Burnout".

World Health Organization (WHO) consider it as, mental, and physical exhaustion of individuals, feeling of negative behavior towards job, and thinking about demolished self-efficacy (2001). This syndrome has negative impact on worker's health and for the organization. The problem raises it about job demands excessive workload with quantitative dimension, which refer to the quality and complexity of work to be completed (1982). The current research aims to fill a knowledge gap by exploring the effects of GHRM on employee green activity in the workplace. The research aims to make a variety of contributions by expanding awareness of HRM behavior and evaluating employee green behavior in the workplace. Previous studies have not yet sufficiently assumed for the impact of labor engagement when implementing organizational practices. This study contributes to the green HRM within organization to understand the workplace green behavior. Some hypotheses are being followed such as: there is a positive relation between self-efficacy and self-esteem (2016).

\section{Significance of the study}

The objective is to analyze the impact of Green HRM practices and Ethical leadership, with the mediating role of Green Self-efficacy on the Green Behavior of Employees. Employees will explain their actions as employee representation in a partnership with the firm's management (Ahmad, Donia, Khan, \& Waris, 2018). 


\section{Statement of the Research Problem}

Organization because of their negative effects on environment are under great pressure to adopt green business practices and develop similar responsible behavior among employees (Jabbour \& a. Santos, 2008). The objective of this study is to narrate a model of Green HRM practices and Employee Green Behavior in the organization on the basis of literature already available. Empirical studies that address, how ethical leadership influence positively the self-efficacy have some critical gap. Also, GHRM is a western one literature, and gives importance of Asian economic development is considered as central gap for future studies.

\section{Literature Review}

Organizations are challenged to enhance the need for environmental performance, social, and ecological sustainability. The process of managing environment is inextricably connected to the human resource management as it is considered the essential part of the firm(Ardito \& Dangelico, 2018). "Green HRM is the Human Resource Management activities which improves positive environmental outcomes" defined by Renwhick et al. (2013). The GHRM utilizes human capital in the pursuit of creativity in order to achieve environmental management, social responsibility, waste reduction, and a competitive advantage through the learning and development of methods that are completely integrated with the organization's priorities and plans (Renwhick, 2013; Renwick, Redman, \& Maguire, 2008).For the good of the worker, the community, nature, and companies, Green HRM encourages workers to act in a green manner both within and outside the company, maintaining environmental protection (Jabbour \& Santos, 2008; Opatha \& Arulrajah, 2014). Green HRM help the firms to design green workforce that would be able to understand green initiatives. According to(Mishra, 2017), GHRM is carried out through the Human Resource Management process which includes: planning, selection, \& recruitment, training \& development, compensation \& appraisal with the objective to maintain the green environment of employees.

In previous study, self-efficacy is described as the "judgments of people about their skills to perform several tasks, which is the central instrument of self-regulation. Individual's acceptance in their efficacy improves the choices they make, and how much effort they undertake to organize their aspirations (Bandura, 1991). Two authors (Farmer \& Tierney, 2002) initiate that, when seniors support their worker's self-confidence, it enhances the employee self-efficacy. In another report, (Enderle, 1987) described ethical leadership as "a way of thinking that emphasizes the ethical dimensions of managerial decision making and the convergence of ethical laws in the decisionmaking process."According to (Trevio, Hartman, \& Brown, 2000), ethical leadership consists of two parts: 1) the leader as an ethical individual, and 2) the leader as an ethical manager. Setting ethical standards, people orientation, taking ethical action, practicing ethical decision making, and expanding ethical knowledge are five more elements identified by (B. Trevio, Hartman, 2003).According to social learning theory, ethical leadership is described as the use of an encouragement mechanism to influence ethical behaviors among employees (Brown, 2005). Scholarly studies indicate that ethical leadership has a positive effect on employee job performance and encourages positive behavior.

Employee's green behavior nature is pro-social (Chou, 2014). Green behavior refers to any attitude that is favorable to the environment or minimizes the harmful activities.(Steg \& Vlek, 2009). With the sustainable development strategy implementation, green behavior of employees got much attention (Norton \& Wang, 2018). Employee Green behavior has two conditions: task related and proactive green behavior implemented within and outside employee's responsibility respectively (2013). Environmental behavior that is not especially recognized by structured evaluation systems, such as double-sided printing, is described as proactive green behavior. Task-related behavior, on the other hand, is characterized as green behavior applied by employees to bottom-line work tasks such as environmental protection obligations and compliance with environmental standards. 


\section{Relationship between Green HRM Practices and Green Self-efficacy Green Printing}

There is a need in organizations for recycling, eliminating, and reusing waste by green printing, which is accomplished by reducing the amount of printing sources. To generate green awareness among public use, the method of low-VCO (volatile, chemical, Organic) inks, low energy consumption computers, laser cartridges, and recycled papers for printing(Mohan et al., 2020).

\section{Green training \& Development}

Training content must be urbanized capabilities and expertise to integrate instructions and generation of eco values, also to announce the training concept on environmental management. Training should be given for the purpose of efficient energy usage, safety measures, reproducing, and management of waste (Ababneh, 2021). To produce green surveillance at work place organizations should use green teams to train employees of upper and lower lever by adopting environment management process. Institutes should encircle the HR representatives with environmental committee, environmental professionals and other authorities.

\section{Green Building}

This term is widely known as green building, which refers to various models and measures that use resources to support the environment. The structure should be based on improved employees productivity, human health, and reducing waste or pollution (Lok \& Chin, 2019).

\section{Green Recruitment}

For increasing the green structure in organizations, they should use updated technology for hiring such as online portal for receiving resumes, company websites, different web portals for applicants to search for a job; it will help to reduce waste created by printing and mailing resumes (Singh, 2020).

\section{Green Employee Retention}

Firms should motivate and encourage their staff to generate sales by reducing pollution through $3(\mathrm{P})$ projects i.e. Pollution, Pay, and Prevention. Environmental problems can be shifted towards green agreements in exclusive way (Mehta \& Mehta, 2017).

H1: GHRM Practices that include green hiring, R\&D, training etc. are positively associated with the Green Self-efficacy.

\section{Relationship between Ethical Leadership and Green Self-efficacy}

The ethical leadership is described as "the implementation of normatively acceptable personal behavior's and interpersonal relationships, as well as their advertising to followers through two-way communication and decision making" (Shakeel et al., 2019). Studies prove that ethical leadership plays important part in motivating whistle blowing. Ethical leadership reduces perception of organizational politics (POP). Since management with ethical skills is trustworthy, free from biasness, and legitimate, they might not approve political activities in the organization and do not appraise selfserving attitudes in organizational personnel (Men et al., 2020).

The framework is expanded upon throughout the study by conducting two surveys with timed breaks to obtain data from diverse industries. Environmental consciousness promotes the indirect influence of Ethical Leadership on Employee Green Action. The results revealed that organisations may focus on Employee Green Behaviour, such as energy conservation, recycling, and carbon reduction, among other things. The study elaborates on several methods by which institutions might strategically focus on green behaviour of employees by conserving energy, recycling waste goods, and other waste products. Scholars in the fields of sustainable development and organizational green behavior focused on corporate leaders' role in encouraging employee green behavior. The research develops hypotheses 
based on social learning theory (Javed et al., 2018). Leaders are generally considered appropriate models for normative attitude. Ethical leaders are supposed to earn "integrity" among their team. The study shows that managers play vital role in making green ethical climate ultimately minimizing the mismanagement in between their workers.

H2: $\quad$ Ethical Leadership is positively associated with Green Self-efficacy.

\section{Relationship between Green Self-efficacy and Employee Green Behavior}

Green attitude at workplace is pre-social in nature (Chou, 2014). Two types of behavior participates in green employee behavior for value creation in organizations are in-role, and extra-role green behavior of employees, depends on the firm and its expectations (Paillé \& Boiral, 2013). There will be a variety of job openings in the future that require employees to behave in a green manner, such as not dumping hazardous waste into bodies of water. Both in-role and extra-role green behaviors are considered as vital component in achieving green organizational objective (2014). The research paper elaborates about the role of Human Resource Management in accomplishing environmental sustainability and affirms on the important requirement to enclose sustainability dimensions within HR arrangements to achieve green environmental goal (Chaudhary \& Management, 2020).

Green HRM practices could be best implemented to affect Employee Green Behavior by depending on AMO (ability, motivation, and opportunity) theory components. The green recruitment assures that only applicants with regulated environmental values are selected. Green opportunities provide workers a chance to give feedback and suggestions that would moderate the performance of Employee Green Behavior. This study narrates that, GHRM influence EGB by personal moral norms mediating the relationship. Affective GHRM practices consequently affect the green behavior of employees. EGB plays a vital role in supporting the environmental management system in the organization (Fawehinmi, Yusliza, Wan Kasim, Mohamad, \& Sofian Abdul Halim, 2020).

H3: There exists a significant relationship between Green Self-efficacy and Employee's Green Behavior.

\section{Green Self-Efficacy as a Mediator}

Self-efficacy is an "assumption" that people have about their scope to manage their surroundings and impact the way they act, perceive, and feel regarding future plans(Bandura, 1977). Self-esteem is considered as the global negative and positive assessment an individual has about self-worth (Rosenberg, 1965). Workers with positive confidence about self-efficacy answer adaptively to predicting positive states on job stressors (e.g. engagement) (2018).Workers with ineffective characteristics failure with lack of competence, maximizing their feeling of inefficacy (2017). Individuals can make choices related to their aspirations, and how much effort they put in a given time period by believing on their efficacy (Bandura, 1991). The ultimate intention of this study was to examine the mediating role of Green Self-efficacy on Green Behavior of employees in diverse industries. Study affirmed that green self-efficacy behaves as a protective variable. It was clarified that work pressure/ overloading is mediated by self-efficacy beliefs, and that the influence of selfefficacy on workload would reduce the negative effects of work pressure.

By concluding all the study, the analysis of the relationship was established among different variables and their effect. The research expands on theories of sustainable practice from the perspective of environmental management and offers suggestions for developing green sustainable practices (Guo, $\mathrm{Xu}$, Liu, \& Wang, 2019). The research concludes that, environmental regulation cannot only connect with green self-efficacy but also with its transmission process. The study narrates the distinctive perspective about how firms can promote employee's green behavior and social responsibilities under strategic development (Zhang, Sun, Xu, \& Health, 2020). 
H4: Green Self-efficacy significantly mediates the relationship between Green HRM Practices and Employee's Green Behavior.

H5: Green Self-efficacy significantly mediates the relationship between Ethical Leadership and Employee's Green Behavior.

\section{Conceptual Framework}

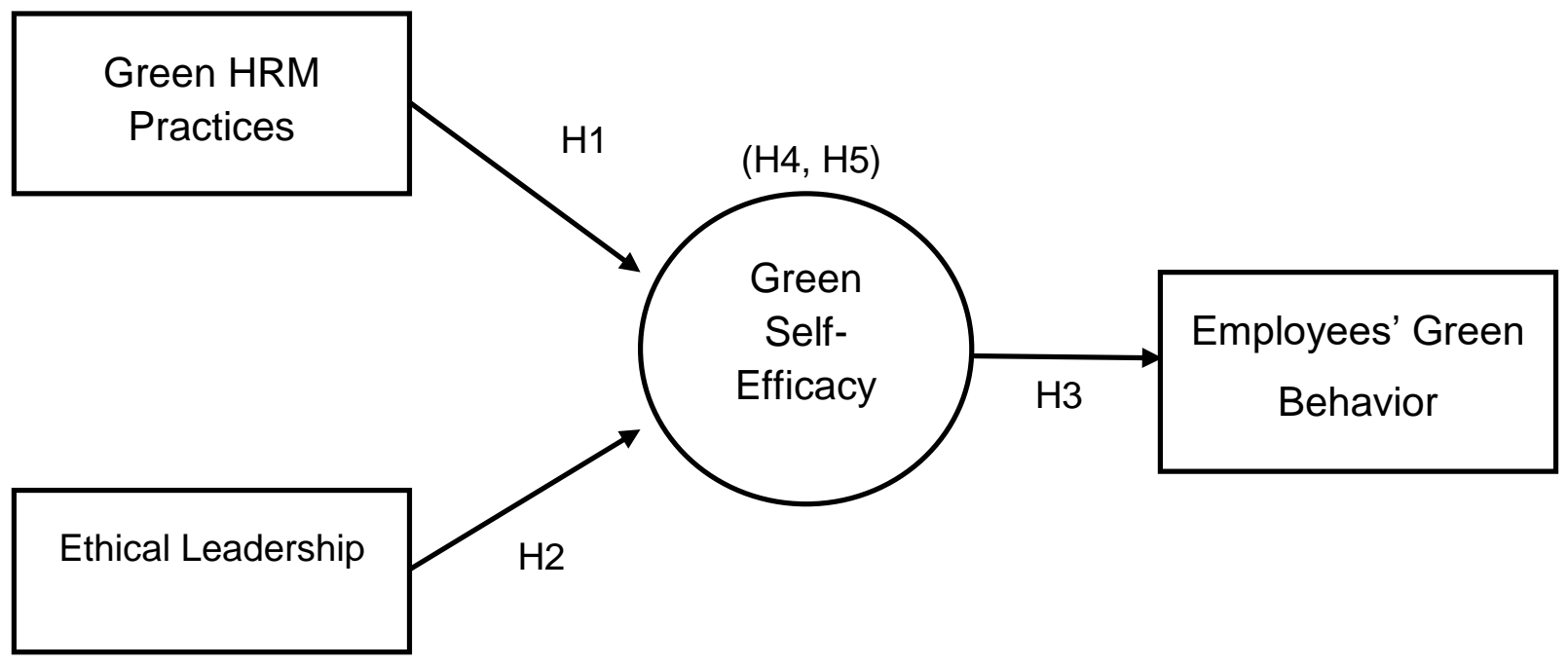

Figure 1: Research Model

\section{Methodology}

In this research, the data was collected through multilevel data questionnaire from 250 employees working within renowned diversified industries of Multan and Lahore region.

\section{Measurement}

For measuring the Green HRM Practices was measured by the scale given by Jabbour, Santos, and Nagano (2010). To measure, employee pro-environmental behavior scale by Kaiser, Oerke, and Bogner (2007) was used. Scale developed by the Schwarzer and Jerusalem in (1995) was used to measure the self-efficacy of employees. Ethical leadership will be examined by using the scale of Brown's (2006). The survey instrument was initially written in English. The items were all rated on a five-point Likert scale ( $1=$ strongly disagree to $5=$ strongly agree).

\section{Tools and techniques}

The quantitative data was analyzed by using SPSS and Smart PLS 3.0.

\section{Results And Findings Pearson Correlation analysis}

In this study the Pearson correlation coefficient was used. Pearson's correlation coefficient is a test statistic used to assess the statistical relationship, or association, between two continuous variables. Because it is based on the concept of covariance, it is recognized as the best way of assessing the connection between variables of interest. Pearson Correlation coefficients having scales between 0.5 and 0.7 indicate variables that can be assumed moderately correlated. In this study, correlation coefficients whose magnitudes are between 0.3 and 0.5 , such as Ethical Leadership (0.185), Green Human Resource Management Practice (0.149), and Green Self Efficacy (0.279), show a low correlation. Pearson's correlation coefficient is a test that determines the statistical link, or association, between two continuous variables. Because it is based on the 
concept of covariance, it is often regarded as the best approach for assessing the relationship between variables of interest. Shown in the table 1 below.

Table \#1: Pearson Correlation analysis

\begin{tabular}{|c|c|c|c|c|c|c|}
\hline & & & $\begin{array}{l}\text { Employee } \\
\text { Green } \\
\text { Behavior }\end{array}$ & $\begin{array}{l}\text { Ethical } \\
\text { Leadership }\end{array}$ & $\begin{array}{l}\text { Green } \\
\text { HRM } \\
\text { Practice }\end{array}$ & $\begin{array}{l}\text { Green } \\
\text { Self } \\
\text { Efficacy }\end{array}$ \\
\hline \multirow{3}{*}{$\begin{array}{l}\text { Employee } \\
\text { Behavior }\end{array}$} & \multirow{3}{*}{ Green } & Pearson Correlation & 1 & $.185^{* * *}$ & $.149^{* * *}$ & $.279^{* * *}$ \\
\hline & & Sig. (2-tailed) & & .001 & .005 & .000 \\
\hline & & $\mathrm{N}$ & 350 & 350 & 350 & 350 \\
\hline \multirow{3}{*}{\multicolumn{2}{|c|}{$\begin{array}{l}\text { Ethical } \\
\text { Leadership }\end{array}$}} & Pearson Correlation & $.185^{* *}$ & 1 & $.410^{* * *}$ & $.239^{* *}$ \\
\hline & & Sig. (2-tailed) & .001 & & .000 & .000 \\
\hline & & $\mathrm{N}$ & 350 & 350 & 350 & 350 \\
\hline \multirow{3}{*}{$\begin{array}{l}\text { Green } \\
\text { Practice }\end{array}$} & \multirow{3}{*}{ HRM } & Pearson Correlation & $.149^{* *}$ & $.410^{* * *}$ & 1 & $.130^{*}$ \\
\hline & & Sig. (2-tailed) & .005 & .000 & & .015 \\
\hline & & $\mathrm{N}$ & 350 & 350 & 350 & 350 \\
\hline \multirow{3}{*}{$\begin{array}{l}\text { Green } \\
\text { Efficacy }\end{array}$} & \multirow[t]{3}{*}{ Self } & Pearson Correlation & $.279^{* *}$ & $.239^{* *}$ & $.130^{*}$ & 1 \\
\hline & & Sig. (2-tailed) & .000 & .000 & .015 & \\
\hline & & $\mathrm{N}$ & 350 & 350 & 350 & 350 \\
\hline
\end{tabular}

\section{Regression Analytics}

Regression analysis is a collection of statistical approaches for estimating linear correlation between two variables such as independent and dependent variables. ANOVA represents the Ftest to determine the extent of variability between group means is either larger or not, than the variability of the observations within the groups. The test indicated that F-test is (12.479) and it shows that ratio is low; this study concludes that not all the means are equal. The table 2 below shows the output of the ANOVA analysis and whether there is a statistically significant difference between our variable's interrelationship means. The result shows the significance value is 0.000 , which is below 0.05 , and, therefore, there is a statistically significant relationship between independent variables Green Self Efficacy, Green Human Resource Management Practice, Ethical Leadership and Employee Green Behavior. R-Square explains that all independent variable shows $31.2 \%$ variation in the dependent variable.

Table 2.1: Regression analysis

\section{MODEL SUMMARY}

\begin{tabular}{lllll} 
Model & R & R Square & Adjusted R Square & $\begin{array}{l}\text { Std. Error of the } \\
\text { Estimate }\end{array}$ \\
\hline 1 & $.312^{\mathrm{a}}$ & .098 & .090 & .50159 \\
\hline
\end{tabular}

Table 2.2: ANOVA results

\begin{tabular}{|c|c|c|c|c|c|c|}
\hline ANOV & & & & & & \\
\hline Model & & Sum of Squares & df & $\begin{array}{l}\text { Mean } \\
\text { Square }\end{array}$ & $\mathbf{F}$ & Sig. \\
\hline 1 & Regression & 9.418 & $\begin{array}{l}3 \\
605\end{array}$ & 3.139 & 12.479 & $.000^{\mathrm{b}}$ \\
\hline
\end{tabular}




\begin{tabular}{llll}
\hline Residual & 87.050 & 346 & .252 \\
\hline Total & 96.469 & 349 &
\end{tabular}

a. Dependent Variable: Employee Green Behavior

b. Predictors: (Constant), Green Self Efficacy, Green Human Resource Management Practice, Ethical Leadership

\section{Beta Coefficients}

The results showed positive coefficients for Ethical Leadership (Beta: 0.078), Green Human Resource Management Practice (Beta: 0.072), Green Self Efficacy (Beta: 0.241078) and Employee Green Behavior. The interpretation demonstrates that the outcome variable will increase by the Beta coefficient value with every 1-unit increase in the predictor variable. If the beta coefficient comes negative, the outcome variable will decrease by the Beta coefficient value with every 1-unit rise in the predictor variable.

Table 2.3: Beta Coefficients summary

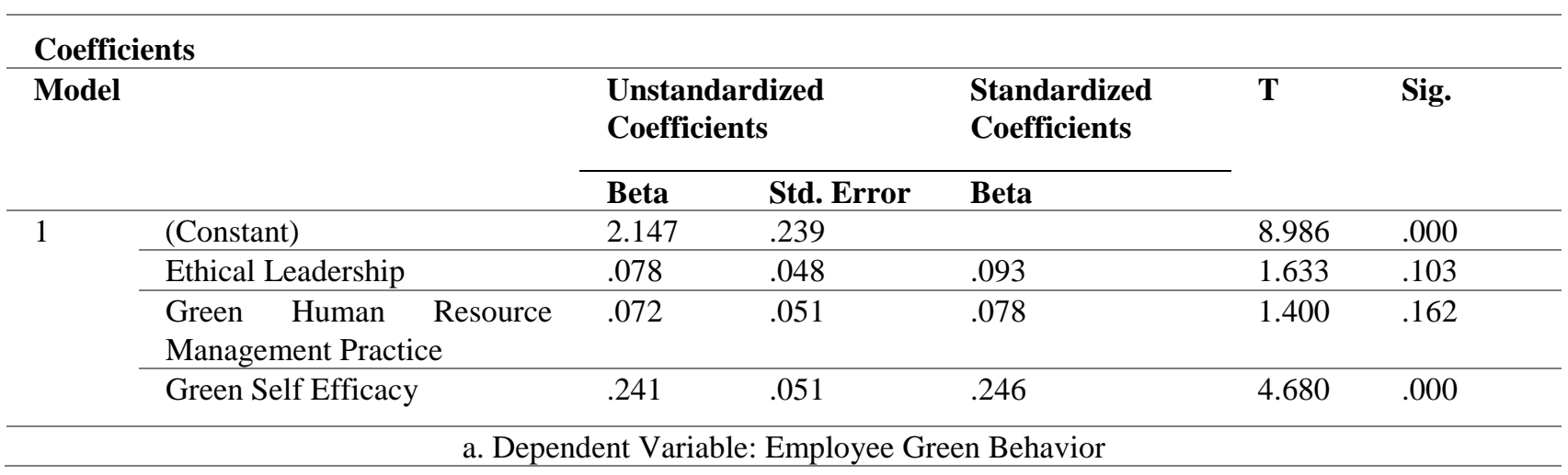

\section{Measurement Model Analysis \\ Factor Loadings}

Items with a value of less than 0.5 should be eliminated, according to Hair et al. (2006), in order to enhance the average variance extracted (AVE) value. They went on to say that lowering values below 0.5 is important to eliminate measurement errors and improve overall SEM model fit. Adhering to their suggestion, the researcher dropped the following items; Employee Green Behavior (EMPGBH13 (-0.11476), EMPGBH15 (0.141264), EMPGBH18 (0.131913), EMPGBH2 (-0.00611), EMPGBH4 (0.212601), EMPGBH5 (0.228908)) and Green Human Resource Management Practices (GHRM1 (0.10465), GSLFEFF11 (0.195215), and GSLFEFF17 (0.171654). 


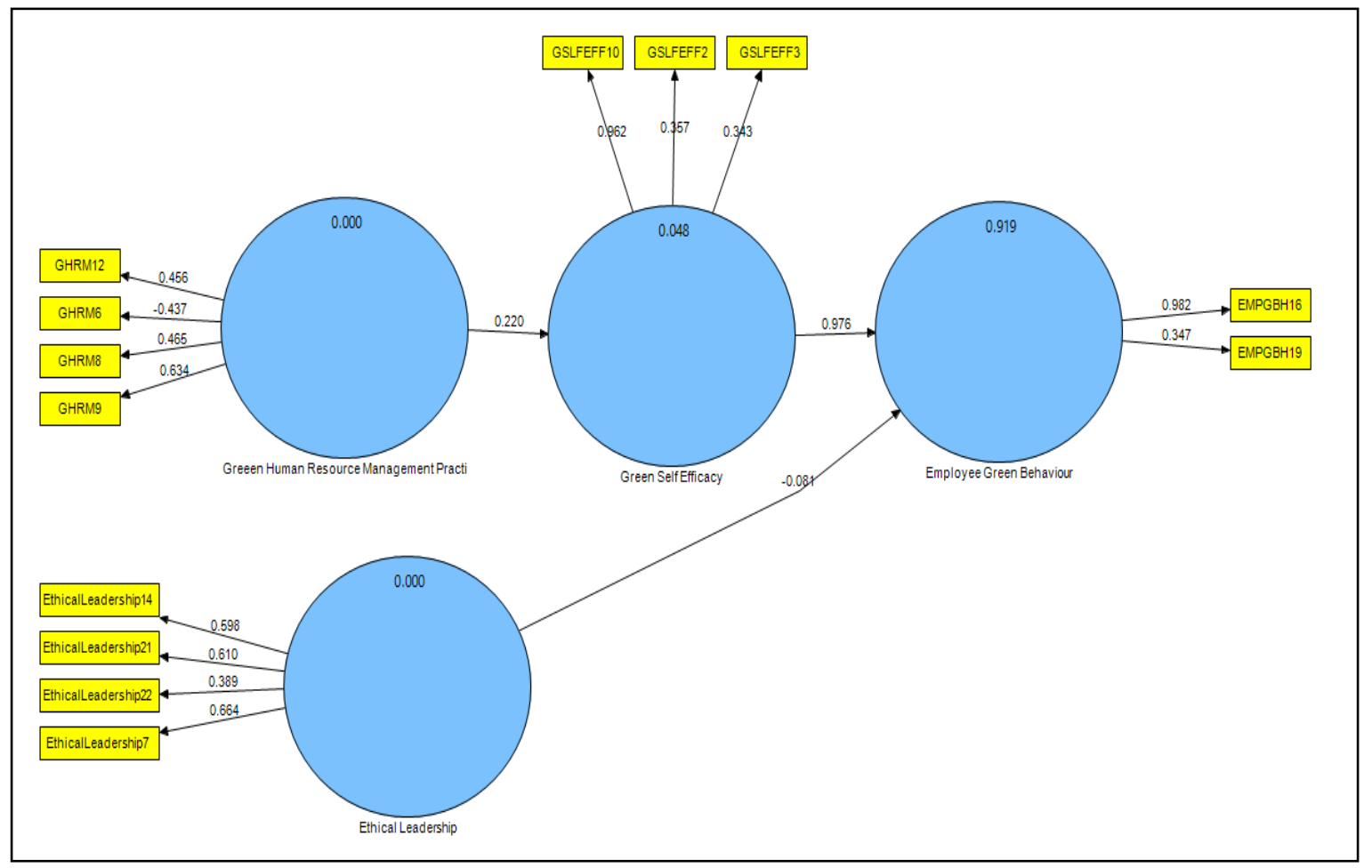

Figure \#2: Measurement Model - Actual

Table 3.1: Factor Loadings

\begin{tabular}{|c|c|c|c|c|c|}
\hline \multirow[t]{2}{*}{ Variables } & \multirow[t]{2}{*}{ Codes } & \multirow{2}{*}{$\begin{array}{l}\text { Actual } \\
\text { Loadings }\end{array}$} & \multirow[t]{2}{*}{ Outer } & & After \\
\hline & & & & \multicolumn{2}{|l|}{ Deleting Items } \\
\hline \multirow[t]{8}{*}{ Employee Green Behavior } & EMPGBH13 & -0.11476 & & Item Eliminated & \\
\hline & EMPGBH15 & 0.141264 & & Item Eliminated & \\
\hline & EMPGBH16 & 0.952902 & & 0.982043 & \\
\hline & EMPGBH18 & 0.131913 & & Item Eliminated & \\
\hline & EMPGBH19 & 0.375632 & & 0.347115 & \\
\hline & EMPGBH20 & -0.006107 & & Item Eliminated & \\
\hline & EMPGBH4 & 0.212601 & & Item Eliminated & \\
\hline & EMPGBH5 & 0.228908 & & Item Eliminated & \\
\hline \multirow[t]{4}{*}{ Ethical Leadership } & EthicalLeadership14 & 0.541885 & & 0.598042 & \\
\hline & EthicalLeadership21 & 0.593842 & & 0.610111 & \\
\hline & EthicalLeadership22 & 0.34602 & & 0.389314 & \\
\hline & EthicalLeadership7 & 0.735075 & & 0.663685 & \\
\hline \multirow[t]{5}{*}{ Green HRM Practices } & GHRM1 & 0.10465 & & Item Eliminated & \\
\hline & GHRM12 & 0.49578 & & 0.456418 & \\
\hline & GHRM6 & -0.441209 & & -0.437338 & \\
\hline & GHRM8 & 0.465614 & & 0.46548 & \\
\hline & GHRM9 & 0.597846 & & 0.633635 & \\
\hline \multirow[t]{5}{*}{ Green Self-efficacy } & GSLFEFF10 & 0.938526 & & 0.962332 & \\
\hline & GSLFEFF11 & 0.195215 & & Item Eliminated & \\
\hline & GSLFEFF17 & 0.171654 & & Item Eliminated & \\
\hline & GSLFEFF2 & 0.390148 & & 0.356686 & \\
\hline & GSLFEFF3 & 0.358424 & & 0.343412 & \\
\hline
\end{tabular}

\section{Interpretation of Measurement Model}

The averages variance extracted (AVE), employee green behavior (0.542448); ethical leadership (0.330483); green human resource management practices $(0.254437)$, and green self-efficacy (0.390413), all of the values greater than the acceptable limit i.e. 0.50 (Bagozzi \& Yi, 1988). In exploratory research, Composite Reliability Coefficients between 0.60 and 0.70 are desirable and acceptable, whereas coefficients between 0.70 and 0.90 are deemed suitable for other forms of 
study. Therefore, in this study it was found that Employee Green Behavior (0.658768); Ethical Leadership (0.656256); Green Human Resource Management Practices (0.795411), and Green Self Efficacy (0.601788) (Sarstedt, Ringle, Smith, Reams, \& Hair Jr, 2014). The R-square of employee green behavior was 0.91896 which explained that $91.89 \%$ variation explained in employee green behavior by all the other variables. The summary of the model is given below and also have mentioned by Figure \#2.

Table 3.2: Summary of Measurement Model

\begin{tabular}{|c|c|c|c|c|}
\hline Variables & AVE & Composite Reliability & Cronbach's Alpha & R Square \\
\hline $\begin{array}{l}\text { Employee } \\
\text { Behavior }\end{array}$ & 0.542448 & 0.658768 & 0.281719 & 0.91896 \\
\hline Ethical Leadership & 0.330483 & 0.656256 & 0.317571 & \\
\hline Green HRM Practices & 0.254437 & 0.795411 & 0.168406 & \\
\hline Green Self Efficacy & 0.390413 & 0.601788 & 0.349552 & 0.048419 \\
\hline
\end{tabular}

\section{Discriminant Validity}

Discriminant validity refers to the degree to which an extent does not correlate with opposing constructs from which it is hypothesized to vary (Malhotra, 2004). By using the square root of the AVE in each latent variable, Fornell and Larcker (1981) concluded that the latent variable's discriminant validity may be established if this value is larger than other correlation values between the latent variables. To accomplish this, a Table was created in which the square root of AVE was manually computed and boldly written on the diagonal. It is shown that the square roots of AVE are larger than other correlations. Employee Green Behavior (0.73651), Ethical Leadership (0.57488), Green Human Resource Management Practices (0.50442), and Green SelfEfficacy (0.62483). Therefore, the result indicates that discriminant validity is significantly formulated for this study. The discriminant value showed satisfactory against Employee Green Behavior.

Table 04: Discriminant Validity

\begin{tabular}{ccccc}
\hline Variables & $\begin{array}{c}\text { Employee Green } \\
\text { Behavior }\end{array}$ & Ethical Leadership & $\begin{array}{c}\text { Green HRM } \\
\text { Practices }\end{array}$ & $\begin{array}{c}\text { Green Self- } \\
\text { Efficacy }\end{array}$ \\
\hline $\begin{array}{c}\text { Employee Green } \\
\text { Behavior }\end{array}$ & $\mathbf{0 . 7 3 6 5 1 0 6 9 2}$ & & & \\
\hline $\begin{array}{c}\text { Ethical } \\
\text { Leadership }\end{array}$ & 0.166762 & $\mathbf{0 . 5 7 4 8 7 6 5 0 8}$ & & \\
\hline $\begin{array}{c}\text { Green HRM } \\
\text { Practices }\end{array}$ & 0.202218 & 0.3631 & $\mathbf{0 . 5 0 4 4 1 7 4 8 6}$ & \\
\hline $\begin{array}{c}\text { Green Self } \\
\text { Efficacy }\end{array}$ & 0.655435 & 0.253635 & 0.220043 & $\mathbf{0 . 6 2 4 8 3 0 3 7 7}$ \\
\hline
\end{tabular}

\section{Hypothesis Testing}

The results of the Smart-PLS show that Green Human Resource Management Practices and Green Self-Efficacy ( $\mathrm{T}$-Statistics $=4.817443, \mathrm{p}=0.045679$ ) because $\mathrm{t}$-statistic is greater than 1.96 and P-Value is less than 0.05, therefore Hypothesis H1 is supported. Moreover, when testing Hypothesis \# 2 (i.e., H2), this study found there is no significant association between Ethical Leadership and Employee Green Behavior (T-Statistics $=1.127155, \mathrm{p}=0.146556$ ) because tstatistic is less than 1.96. It indicates that ethical leadership does not have significant association with employee green behavior. Therefore, hypothesis $\mathrm{H} 2$ is not supported. There is significant relationship between Green Self-Efficacy and Employee Green Behavior $(\mathrm{t}=4.14664$, $\mathrm{p}=0.054016$ ) because t-statistic is greater than 1.96. The relationship between green human resource management practices and employee green behavior is the significant therefore Hypothesis \# 3 (i.e., H3) is supported. Furthermore, Hypothesis \# 4 (i.e., H4) found that Green Self-Efficacy mediated the association between Green HRM Practices and Employee Green 
Behavior $(\mathrm{T}$-Statistics $=9.724802, \mathrm{P}-$ Value $=0.024043)$ because t-statistic is greater than 1.96 and P-Value is less than 0.05 therefore Hypothesis \# 4 (i.e., H4) is supported. In the end this study investigated the mediating effect of Ethical Leadership Between Green Self-Efficacy and Employee Green Behavior found that it partially mediates as the $(\mathrm{T}-$ Statistics $=1.814348, \mathrm{P}$ Value $=0.210848$ )

Table 05: Hypothesis Testing - Direct Relationships

\begin{tabular}{|c|c|c|c|c|c|c|c|c|}
\hline $\begin{array}{l}\text { Hypothesi } \\
\text { s }\end{array}$ & $\begin{array}{l}\text { Relationship } \\
\text { s }\end{array}$ & $\begin{array}{l}\text { Origina } \\
\text { l } \\
\text { Sample } \\
\text { (O) }\end{array}$ & $\begin{array}{l}\text { Sample } \\
\text { Mean } \\
(\mathrm{M})\end{array}$ & $\begin{array}{l}\text { Standar } \\
\text { d } \\
\text { Deviatio } \\
\text { n } \\
\text { (STDEV } \\
\text { ) }\end{array}$ & $\begin{array}{l}\text { Standar } \\
\text { d Error } \\
\text { (STERR } \\
\text { ) }\end{array}$ & $\begin{array}{l}\text { T Statistics } \\
\text { (|O/STERR| } \\
\text { ) }\end{array}$ & $\begin{array}{l}\text { P- } \\
\text { Value }\end{array}$ & $\begin{array}{l}\text { Supporte } \\
\text { d / Not } \\
\text { Supporte } \\
\text { d }\end{array}$ \\
\hline H1 & $\begin{array}{l}\text { Green HRM } \\
\text { Practices } \\
\rightarrow \\
\text { Green Self- } \\
\text { Efficacy }\end{array}$ & $\begin{array}{l}0.22005 \\
6\end{array}$ & $\begin{array}{l}0.23045 \\
6\end{array}$ & 0.045679 & 0.045679 & 4.817443 & $\begin{array}{l}0.04567 \\
9\end{array}$ & Supported \\
\hline H2 & $\begin{array}{l}\text { Ethical } \\
\text { Leadership } \\
\rightarrow \\
\text { Employee } \\
\text { Green } \\
\text { Behavior }\end{array}$ & $\begin{array}{l}0.16519 \\
1\end{array}$ & 0.11246 & 0.146556 & 0.146556 & 1.127155 & $\begin{array}{l}0.14655 \\
6\end{array}$ & $\begin{array}{l}\text { Not } \\
\text { Supported }\end{array}$ \\
\hline H3 & $\begin{array}{l}\text { Green Self- } \\
\text { Efficacy } \\
\rightarrow \\
\text { Employee } \\
\text { Green } \\
\text { Behavior }\end{array}$ & $\begin{array}{l}0.26545 \\
3\end{array}$ & $\begin{array}{l}0.26757 \\
9\end{array}$ & 0.064016 & 0.054016 & 4.14664 & $\begin{array}{l}0.05401 \\
6\end{array}$ & Supported \\
\hline H4 & $\begin{array}{l}\text { Green Self- } \\
\text { Efficacy * } \\
\text { Green HRM } \\
\text { Practices } \\
\rightarrow \\
\text { Employee } \\
\text { Green } \\
\text { Behavior }\end{array}$ & $\begin{array}{l}1.20629 \\
6\end{array}$ & $\begin{array}{l}1.15741 \\
5\end{array}$ & 0.124043 & 0.024043 & 9.724802 & $\begin{array}{l}0.02404 \\
3\end{array}$ & Supported \\
\hline H5 & $\begin{array}{l}\text { Green Self- } \\
\text { Efficacy } * \\
\text { Ethical } \\
\text { Leadership } \\
\rightarrow \\
\text { Employee } \\
\text { Green } \\
\text { Behavior }\end{array}$ & $\begin{array}{l}- \\
0.38255 \\
2\end{array}$ & $\begin{array}{l}- \\
0.30001 \\
2\end{array}$ & 0.210848 & 0.210848 & 1.814348 & $\begin{array}{l}0.21084 \\
8\end{array}$ & $\begin{array}{l}\text { Partially } \\
\text { Supported }\end{array}$ \\
\hline
\end{tabular}

\section{Conclusion}

Rising awareness within the companies about Green Human Resource Practices are still at the early stage. Environmental issues force the organizations to adopt Green Policies which would be environment-friendly. The impacts of these practices need continuous monitoring and are multifaceted. GHRM includes different human resource policies i.e., recycling, double-sided copy etc. and practices linked with the three main components such as; social, economic and environmental balance. The findings of this study will help the organizations to reduce the environmental pollution to make world cleaner and safer. Out of five hypothesis three showed fully significant relationship while Ethical Leadership showed insignificant relationship with Employee Green Behavior. Moreover, Ethical Leadership with intervening variable Green Selfefficacy demonstrated a partial significant relationship with respect to Employee Green Behavior. 
Also, it shows that with the mediating effect of Green Self-Efficacy, GHRM Practices has a significant positive influence on Employee's Green Behavior that will improve the performance level of the company.

\section{Implications of the Research}

Green HRM is a growing paradigm. Certain environmental impacts and the urge to become green can be handled by the application of sustainable HRM by various commercial and public sector entities. The study empirically investigates the relationship between GHRM practices and ethical leadership with employee green behavior via mediating role of self-efficacy which is an novel approach and provide insights for the industrial managers to implement these green practices by enhancing employees self-efficacy. Employers should adequately assess employees' green behavior and match it with compensation and promotion. Businesses must also promote and urge their staff to participate in environmentally friendly practices and result in environmental stewardship.

\section{Future Recommendations}

In an epoch when authorities and customers know that business decisions and actions may cause long-term ecological harm, business leaders are under increasing pressure to bear greater responsibility for maintaining and even rebuilding the Earth's scarce and depleted natural resources. Environmentally friendly corporate methods are becoming increasingly popular, consistent with obtaining a competitive advantage as well as with the moral principles of society(Ren et al., 2020). Considering our study's immense contribution, a few shortcomings must be noted, which provide valuable direction for future research. As a result, it is suggested that future studies add more Green HRM practices into their model to gain an insight into the impact of such activities on employee green behaviors. These extra practices could include sustainability initiatives, green work-life balance, green empowerment, and so on, with a particular emphasis on employee involvement as a critical component of sustainable competitiveness.

Furthermore, future work can employ this study's holistic framework in other industries to explain its applicability in firms with varied fields and workplace environment. Additional studies could use a longitudinal methodological approach to look at the paradigm through a definite period. Furthermore, among the evaluated relationships, the study looked at one mediator, Green Self-efficacy. Other determinants, such as Green Perceived Organizational Support, Green Climate Engagement, and Organizational Identification, may be recommended for future research (Aboramadan, 2020). Lastly, future research may explore the concept in various service areas, such as postsecondary learning, charities, and government institutes, pharmaceuticals and hospitality to see whether there are any disparities between these industries.

\section{References}

Aboramadan, M. (2020). The effect of green HRM on employee green behaviors in higher education: the mediating mechanism of green work engagement. International Journal of Organizational Analysis. https://doi.org/10.1108/IJOA-05-2020-2190

Ahmad, I., Donia, M. B., Khan, A., \& Waris, M. (2019). Do as I say and do as I do? The mediating role of psychological contract fulfillment in the relationship between ethical leadership and employee extra-role performance. Personnel review.

Ardito, L., \& Dangelico, R. M. (2018). Firm environmental performance under scrutiny: The role of strategic and organizational orientations. Corporate Social Responsibility and Environmental Management, 25(4), 426-440.

Bandura, A. (1977). Self-efficacy: toward a unifying theory of behavioral change. Psychological review, 84(2), 191.

Brown, M. E., \& Treviño, L. K. (2003). Is values-based leadership ethical leadership. Emerging 
perspectives on values in organizations, 151-173.

Brown, M. E., Treviño, L. K., \& Harrison, D. A. (2005). Ethical leadership: A social learning perspective for construct development and testing. Organizational behavior and human decision processes, 97(2), 117-134.

Chaudhary, R. J. C. S. R., \& Management, E. (2020). Green human resource management and employee green behavior: an empirical analysis. 27(2), 630-641.

Chou, C. J. (2014). Hotels' environmental policies and employee personal environmental beliefs: Interactions and outcomes. Tourism Management, 40, 436-446.

Dumont, J., Shen, J., \& Deng, X. (2017). Effects of green HRM practices on employee workplace green behavior: The role of psychological green climate and employee green values. Human resource management, 56(4), 613-627.

Enderle, G. (1987). Some perspectives of managerial ethical leadership. Journal of Business Ethics, 6(8), 657-663.

Fawehinmi, O., Yusliza, M., Wan Kasim, W. Z., Mohamad, Z., \& Sofian Abdul Halim, M. A. J. S. O. (2020). Exploring the Interplay of Green Human Resource Management, Employee Green Behavior, and Personal Moral Norms. 10(4), 2158244020982292.

Guo, L., Xu, Y., Liu, G., \& Wang, T. J. S. (2019). Understanding Firm Performance on Green Sustainable Practices through Managers' Ascribed Responsibility and Waste Management: Green Self-Efficacy as Moderator. 11(18), 4976.

Jabbour, C. J. C., \& Santos, F. C. A. (2008). Relationships between human resource dimensions and environmental management in companies: Proposal of a model. Journal of Cleaner Production, 16(1), 51-58. https://doi.org/10.1016/j.jclepro.2006.07.025

Jabbour, C. J. C., Santos, F. C. A., \& Nagano, M. S. (2008). Environmental management system and human resource practices: Is there a link between them in four Brazilian companies? Journal of Cleaner Production, 16(17), 1922-1925. https://doi.org/10.1016/j.jclepro.2008.02.004

Lülfs, R., \& Hahn, R. (2013). Corporate greening beyond formal programs, initiatives, and systems: A conceptual model for voluntary pro-environmental behavior of employees. European Management Review, 10(2), 83-98.

Marin-Garcia, J. A., Tomas, J. M. (2016). Deconstructing AMO framework: A systematic review. Intangible Capital, 12(4), 1040-1087

Mayer, D. M., Kuenzi, M., \& Greenbaum, R. L. J. J. o. b. e. (2010). Examining the link between ethical leadership and employee misconduct: The mediating role of ethical climate. 95(1), 7-16.

Mishra, P. (2017). Green human resource management: A framework for sustainable organizational development in an emerging economy. International Journal of Organizational Analysis, 25(5), 762-788. https://doi. org/10.1108/IJOA-11-2016-1079

Morrison, E. W., \& Milliken, F. J. (2000). Organizational silence: A barrier to change and development in a pluralistic world. Academy of Management review, 25(4), 706-725.

Opatha, H. H. P., \& Arulrajah, A. A. (2014). Green human resource management: Simplified general reflections. International Business Research, 7(8), 101.

Paillé, P., Chen, Y., Boiral, O., \& Jin, J. (2014). The impact of human resource management on environmental performance: An employee level study. Journal of Business Ethics, 121(3), 451-466. https://doi.org/10.1007/s10551-013-1732-0

Ren, S., Tang, G., \& Jackson, S. E. (2020). Effects of Green HRM and CEO ethical leadership on organizations' environmental performance. International Journal of Manpower. https://doi.org/10.1108/IJM-09-2019-0414

Renwick, D. W., Redman, T., \& Maguire, S. (2013). Green human resource management: A review and research agenda. International Journal of Management Reviews, 15(1), 1-14. https://doi.org/10.1111/j.1468-2370.2011.00328.x

Renwick, D., Redman, T., \& Maguire, S. J. U. o. S. M. S. D. P. (2008). Green HRM: A review, process model, and research agenda. 1, 1-46. 
Rosenberg, M. (1965). Rosenberg self-esteem scale (RSE). Acceptance and commitment therapy. Measures package, 61(52), 18.

Saleem, M., Qadeer, F., Mahmood, F., Ariza-Montes, A., \& Han, H. J. S. (2020). Ethical Leadership and Employee Green Behavior: A Multilevel Moderated Mediation Analysis. 12(8), 3314.

Steg, L., \& Vlek, C. (2009). Encouraging pro-environmental behaviour: An integrative review and research agenda. Journal of environmental psychology, 29(3), 309-317.

Tierney, P., \& Farmer, S. M. (2002). Creative self-efficacy: Its potential antecedents and relationship to creative performance. Academy of Management journal, 45(6), 1137-1148.

Trevino, L. K., Hartman, L. P., \& Brown, M. (2000). Moral person and moral manager: How executives develop a reputation for ethical leadership. California management review, 42(4), 128-142.

Wang, X., Zhou, K., \& Liu, W. (2018). Value congruence: a study of green transformational leadership and employee green behavior. Frontiers in psychology, 9, 1946.

Zhang, W., Sun, B., Xu, F. J. I. J. o. E. R., \& Health, P. (2020). Promoting Green Product Development Performance via Leader Green Transformationality and Employee Green Self-Efficacy: The Moderating Role of Environmental Regulation. 17(18), 6678. 